\title{
Macro-regional differentiation of the world: Authors' concept and its application
}

\section{Abstract}

This article is a continuation of the same authors' study entitled 'Concepts And Delimitation Of The World's Macro-Regions' prepared for the 1/2018 of this journal (Anděl et al. 2018). The main aim of the first part was an evaluation of the concepts and factors which have been used as a basis for the delimitation of the different macro-regions of the world. In this second part, the authors propose their own macro-regionalisation of the world this is a combination of four concepts, with relatively different contents: those of De Blij and Muller (1997), Cole (1996), Huntington (1996) and Hampl (2009). This macro-regionalisation arises from sociocultural affiliation, economic interrelationships and territorial continuity. Along with the concept of the macro-regional differentiation of the world itself, we focus on evaluating the importance of the shaping of macro-regions, as well as assessing the positive and negative features of individual concepts and their influence on the macro-regional differentiation of the world.

\section{Keywords}

Regional geography • geography of the world • differentiation of the world • global macro-regions $\cdot$ concepts and factors of regionalization

(C) University of Warsaw - Faculty of Geography and Regional Studies

\author{
J. Anděl', I. Bičík ${ }^{2}$, J. D. Bláha ${ }^{1}$ \\ IJ. E. Purkyně University in Ústí nad Labem, \\ Faculty of Science, Department of Geography, \\ Ústi nad Labem, Czechia \\ e-mail: jiri.andel@ujep.cz \\ e-mail: jd@jackdaniel.cz \\ ${ }^{2}$ Charles University, Faculty of Science, \\ Department of Social Geography and Regional \\ Development, Prague, Czechia \\ e-mail: ivan.bicik@natur.cuni.cz \\ Received: 18 December 2017 \\ Accepted: 21 August 2018
}

\section{Introduction}

Neither the Czech nor the foreign literature focused on global macro-regional delimitation give enough methodological approaches to argue for methods of delimitation. The unsuitable examples provided include some textbooks (Jackson \& Hudman 1990; Hobbs \& Dolan 2009), as well as the delimitation applied by the United Nations (UN 2012). A code system (M 49) is applied which delimitates macro-regional and sub-regional territories. The borders of the macro-regions are arranged to mirror the borders of the continents (America is delimitated by the North and Latin borders). Continents are sub-divided into four or five units (according to the main cardinal directions, supplemented by the term "Central"). One of the bad examples is that of North Europe, which also includes the Baltic states and the British Isles. Within this, delimitation Czechia is included in East Europe, where the entire Russian Federation is also located!

The authors present their own macro-regionalisation of the world which constitutes a synthesis or a combination of four main concepts, the contents of which are relatively different (those by De Blij \& Muller 1997; Cole 1996; Huntington 1996 and Hampl 2009). Hampl's concept arises from sociocultural identity, economic interrelationships and territorial continuity. It integrates social, cultural and economic elements, while also trying to construct macro-regions as relatively contiguous territorial units on a similar scale (part 4). Along with the concept of the macroregional differentiation of the world itself, we focus on evaluating the importance of dividing the world into macro-regions, assessing the positive and negative features in comparison with the classical, continental division of the world.
Methodology

The delineation of the macro-regions of the world is a very complicated affair because the creation of comprehensive groupings at this level can only approximately approach an objective reality. Any attempt inherently includes the latent subjective character of those who conduct the delineation and the data they choose to use. However, there will always be a 'better' choice among all the possible bad solutions (Anděl \& Bičík 2015).

When devising macro-regions of the world, there is the decisive methodological problem of finding the aggregate which would at least generally reflect both social and economic aspects as well as basic political or environmental viewpoints. This concept is probably closest to the differentiation of the world according to civilisations which have a certain degree of integration and constitute the broadest cultural entity (Huntington 1996). Studies focusing on analysing the global system (Wallerstein 1979) should undoubtedly also have an impact on the macroregionalisation of the world. They are based on the acceptance of the polarity of the node - (semi-periphery) - periphery, not only on the regional level, but also on the global level. This concept has been adopted by a number of geographers (Agnew 1999; Taylor \& Flint 1999; Hampl 2014, etc.). Although the reach of these studies is very broad and encompasses political, social and economic aspects, the resulting view of global differentiation tends to be economic in focus.

One important issue is the number of macro-regions. This can vary considerably according to individual authors: from six (continental concept) or eight (Clawson 2007; Huntington 1996) up to fifteen (Morris 1972). The role of a point of departure for macro- 


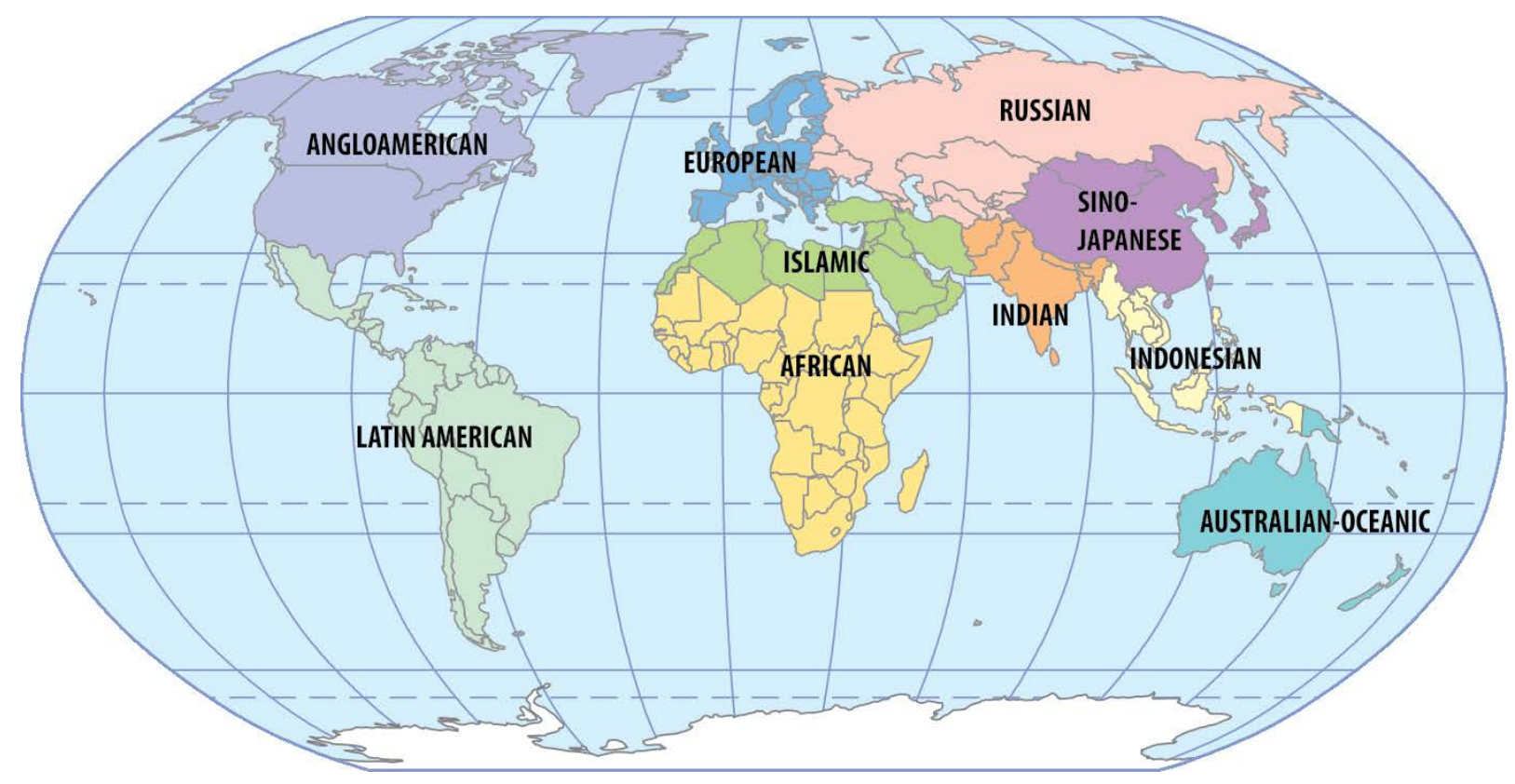

Figure 1. The authors' regionalisation of the world into macro-regions. Scale: 1:220,000,000. Source: Authors

regionalisation of the present-day world can be played by the civilisation approach as it includes elements and viewpoints which are not only cultural, but also economic, political, military and social (although often in a mediated way).

The authors' concept is based on our previous experience in trying to observe the following propositions, as well as technical and methodological inputs. We divide the world into ten relatively homogeneous units (unlike heterogeneous continents), while primarily aiming to evaluate macro-regions as a whole. Secondly, we point out their possible internal regional differentiation. Use is made of the analogous structure of the evaluating factors for all macro-regions, for the sake of their easy comparison. Methodologically, this is a synthesis which combines, above all, four concepts with differing contents: those of De Blij and Muller (1997), Cole (1996), Huntington (1996) and Hampl (2009). The primary factor is sociocultural (civilisation) affiliation, generally reflecting Huntington's concept and division (1996). The second factor reflects economic interrelationships and, at the same time, similarities in the level of maturity, while the last factor reflects geographic continuity, not only in the sense of territorial continuity, but particularly in the sense of respecting the internal integrity of the macro-areas. In doing so, it integrates social, cultural and economic elements, at the same time trying to devise macroregions as relatively contiguous territorial units with a similar scale (Figure 1).

The delineation of macro-regions is also associated with the major problem of naming them. In individual concepts, the names tend to determine the position of a macro-region on the landmass. This often brings about the creation of a very complicated name, as in the case of South-Western Asia and Northern Africa or, in Huntington's concept, the names of civilisations. In this publication, the authors partly exploit the names already used by Hampl (2009) in order to view the level of integrity of subglobal systems. The names mostly reflect cultural geographical specificities (AngloAmerican, Latin American macro-regions) or the dominance of civilisation aspects (Islamic macro-region). Names are frequently given according to the states dominating a given macro-region (Indonesian, Indian or Sino-Japanese macro-regions). Unlike the macro-regionalisation used by the authors in 2010 (Bičík et al. 2010), there were certain modifications, the most substantial ones being associated with the Sino-Japanese macro-region (Eastern Asia). This was differentiated in the previous variant into two parts - the less advanced macro-region (China, North Korea and Mongolia) and the advanced macro-region (Japan, South Korea and Taiwan) of Eastern Asia. There was also a different delineation of the Islamic macro-region (South-Western Asia and Northern Africa).

The authors partly took into account and verified the delineation of macro-regions of the world through mental maps which represent the depiction of individuals' spatial ideas of the arrangement and regionalisation of the world (such as Saarinen 1988; Polonský et al. 2010; Bláha \& Nováček 2016). Aggregated mental maps from groups of addressed individuals provide valuable information in connection with the concepts of regionalisation. This can be exemplified by a study of the mental maps of Czech geography students (Polonský et al. 2010), which presents the delineation of ten macro-regions (Figure 2) and compares this delineation with the concepts of regionalisation in literature. The similarity of the results is far from random, because people's spatial ideas of the regionalisation of the world are mainly influenced by the media and textbooks. On the other hand, it is obvious that mental maps of individuals from various regions and cultures show considerable differences. This is why the view presented here is that of a member of the Western civilisation circle. As evidenced, for example, by Bláha \& Nováček (2016), whose work was devoted to the delineation of the Central European region, the degree of identification of a space with the name of a region whose borders may have a fuzzy character can also be monitored.

\section{Results}

The world is differentiated into ten macro-regions in order to maintain the maximum possible homogeneity in terms of social and economic maturity as well as cultural integrity (see Figure 1).

1. The European macro-region does not include Belarus, Ukraine or Moldova, which were included in the Russian macroregion. The role of integrating element is played by European 


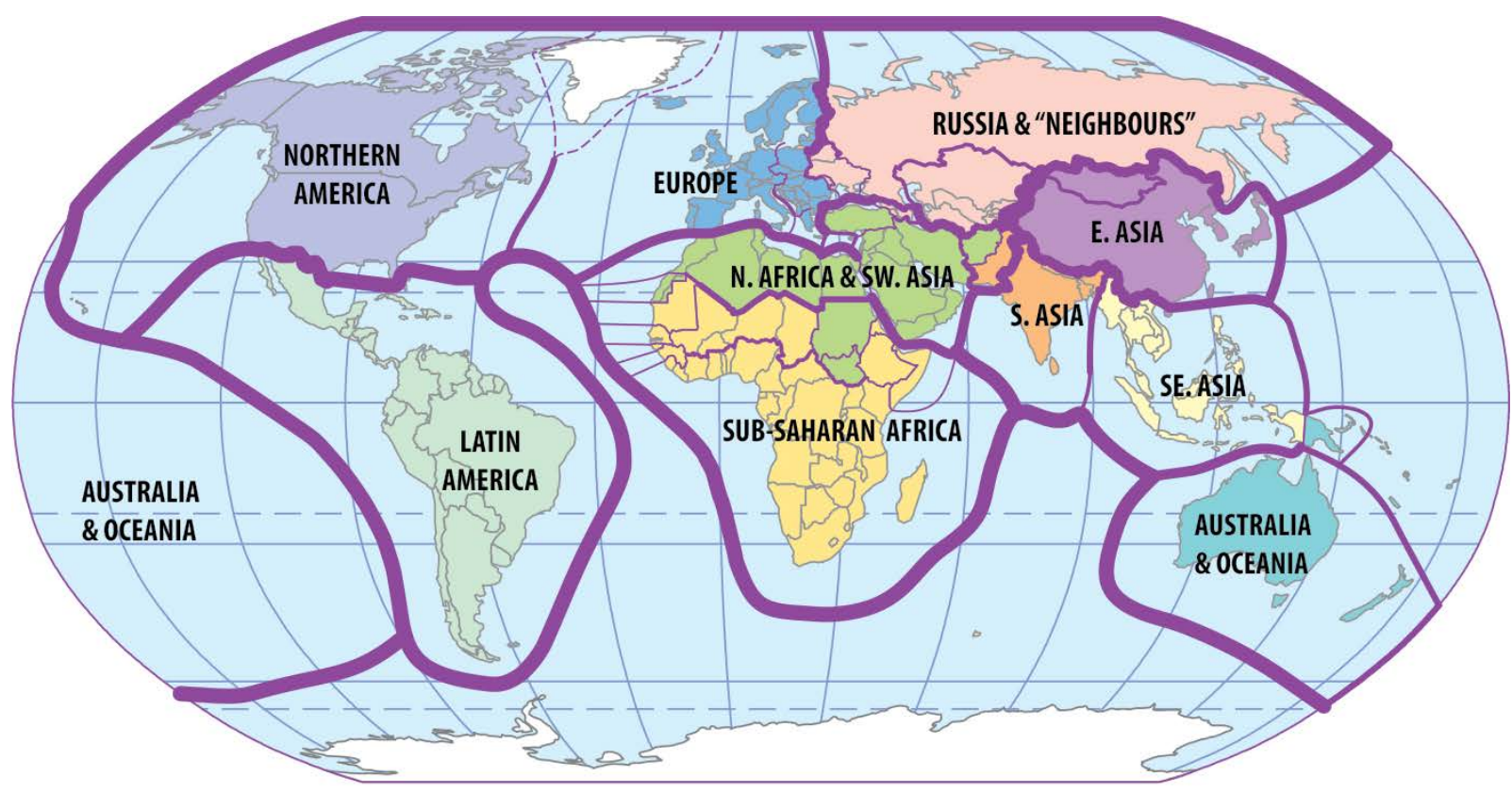

Frequency of particular segment borderline by students

dependent territory borderline (Greenland)

$\begin{array}{lllll}100 & 80 \quad 60 & 40 & 20\end{array}$

N. Northern

E. Eastern

S. Southern

W. Western (...)

Figure 2. Regionalisation of the world on the basis of mental maps from Czech geography students. Scale: 1:220,000,000. Source: Authors' elaboration based on Polonský et al. 2010

civilisation, referring to people's cultural, social and moral values. This is the macro-region in which the most important revolutions of mankind occurred - from the Industrial Revolution to the demographic and democratic revolutions - and from which a multitude of innovations have spread. It is characterized by the high living standards of the population (the highest life expectancy among the macro-regions: 78 years for men and 83 years for women, with almost $100 \%$ literacy). Along with the Anglo-American macro-region, it creates the highest GDP among the macro-regions $-25.6 \%$ of the world's GDP (see Table 1 ). It has a specific feature in the form of relative economic and cultural homogeneity, primarily based on Christianity, the impact of which has lasted for centuries. European identity is also formed by the European Union. This is a project unparalleled in the world, where the integration of states has reached the highest degree. This is the macro-region which has most influenced other macroregions. We rank it among the global core areas.

2. The Anglo-American macro-region comprises the USA, Canada and Greenland. The role of integrating factor is played not only by the English language, but also by the settlement history of the area; in recent years, much has been said about the American consumer society. However, at present the cementing tendencies are also influenced by the idea of a giant, wealthy power with an impact on the developments of the contemporary world, in terms of the economy, politics and culture. The economically prosperous macro-region (which contributes to the creation of $25.3 \%$ of the world's GDP) constitutes a powerful carrier of globalisation processes, marked with a strong economic and cultural homogeneity. The USA had already become a global economic and political superpower by the early $20^{\text {th }}$ century and its distance from other countries became even more pronounced after WWII. An even more important role is played by the USA in the political sphere, through which it intervenes in the political and economic affairs of the whole world.

3. The Russian macro-region (Northern Eurasia) is identical to the territory of the former Soviet Union with the exception of the Baltics, an area repeatedly dominated by Russia (or the Soviet Union). In terms of area, it is the biggest of the macro-regions (16.2\% of habitable land). The Russian macro-region is primarily integrated by the remnants and consequences of the former Soviet Union (Russification, centralist model of administration, prevailing influence of Communist ideology, corruption, etc.), but also by considerably differentiated natural conditions. There is a negative cementing element of tremendous discrepancies between core and peripheral areas, which implicates discrepancies between rich and poor inhabitants. There is a relatively low value of GDP per capita and, in particular, a low life expectancy, especially for men (only 65 years). Other problems include large transport distances and the low value added of industrial production, as well as the focus on the export of raw materials and arms systems.

4. The Australian-Oceanic macro-region has by far the smallest proportion of the global population (only $0.5 \%$ ) and an extremely low population density of 4.5 inhabitants per $\mathrm{km}^{2}$. Its population has a large anthropological and linguistic diversity (thanks largely to history and immigration). There are still big contrasts in the level of the economy and the overall development of society between Australia or New Zealand on the one hand and certain Pacific islands (such as the Solomon Islands) on the other. There is a clear economic, political and population dominance of a single state - Australia. The advanced economy of New Zealand is in the shadow of the Australian economy, while the island states in the Pacific Ocean are just 'economic dwarfs' in comparison. 
MISCELLANEA GEOGRAPHICA - REGIONAL STUDIES ON DEVELOPMENT

Vol. $22 \cdot$ No. $3 \cdot 2018 \cdot$ pp. 117-122 •ISSN: 2084-6118 • DOI: 10.2478/mgrsd-2018-0025

Table 1. Basic indicators of macro-regions and integrity level (2016)

\begin{tabular}{|c|c|c|c|c|c|c|c|c|c|}
\hline \multirow{2}{*}{ Macro-region } & \multirow{2}{*}{$\begin{array}{c}\text { Area } \\
\%\end{array}$} & \multirow{2}{*}{$\begin{array}{c}\text { Population } \\
\%\end{array}$} & \multirow[t]{2}{*}{$\begin{array}{c}\text { Population } \\
\text { per } \mathbf{k m}^{2}\end{array}$} & \multirow{2}{*}{$\begin{array}{c}\text { GDP } \\
\%\end{array}$} & \multirow{2}{*}{$\begin{array}{c}\text { GDP ppp } \\
\text { USD }\end{array}$} & \multirow{2}{*}{$\begin{array}{c}\text { Literacy } \\
\%\end{array}$} & \multirow{2}{*}{$\begin{array}{c}\text { Life } \\
\text { expectancy } \\
\text { Age } \mathrm{M} / \\
\text { Age } \mathrm{F}\end{array}$} & \multicolumn{2}{|c|}{ Homogeneity } \\
\hline & & & & & & & & economic & cultural \\
\hline European & 3.7 & 7.3 & 106.0 & 25.6 & 38,000 & 100 & $78 / 83$ & $* * \star$ & $\star \star \star *$ \\
\hline $\begin{array}{c}\text { Anglo- } \\
\text { American }\end{array}$ & 16.0 & 4.9 & 16.5 & 25.3 & 54,000 & 99 & $77 / 82$ & $* * *$ & $* * *$ \\
\hline Russian & 16.2 & 3.8 & 13.0 & 3.2 & 18,000 & 100 & $65 / 75$ & $* \star *$ & $* * *$ \\
\hline $\begin{array}{l}\text { Australian- } \\
\text { Oceanic }\end{array}$ & 6.2 & 0.5 & 4.5 & 2.2 & 35,000 & 95 & $75 / 79$ & $* * *$ & $* * *$ \\
\hline $\begin{array}{c}\text { Sino- } \\
\text { Japanese }\end{array}$ & 8.6 & 22.6 & 141.0 & 22.0 & 16,000 & 95 & $66 / 70$ & ** & $* * *$ \\
\hline Indonesian & 3.3 & 8.5 & 140.0 & 2.9 & 10,000 & 91 & $68 / 74$ & ** & $* *$ \\
\hline Indian & 3.7 & 23.7 & 344.0 & 3.4 & 4,000 & 57 & $67 / 70$ & ** & * \\
\hline Islamic & 8.9 & 6.8 & 41.0 & 5.8 & 17,000 & 75 & $71 / 75$ & $* \star$ & $* * \star$ \\
\hline $\begin{array}{c}\text { Latin } \\
\text { American }\end{array}$ & 15.0 & 8.5 & 31.0 & 7.4 & 16,000 & 90 & $72 / 79$ & ** & $* \star *$ \\
\hline African & 18.4 & 13.4 & 40.0 & 2.2 & 4,000 & 64 & $57 / 60$ & * & * \\
\hline Total & 100.0 & 100.0 & 54.0 & 100.0 & 10,000 & 80 & $68 / 72$ & . & . \\
\hline
\end{tabular}

Notes: GDP ... Gross Domestic Product, GDP ppp ... Gross Domestic Product based on purchasing power parity, USD ... United States dollar, M ... male, F ... female; * ${ }^{* *},{ }^{* * *}$ level of homogeneity (from bottom up). Source: the World Bank, the CIA World Factbook, the United Nations

5. The Sino-Japanese macro-region (Eastern Asia) comprises China, Japan, North Korea, South Korea, Taiwan and Mongolia. The region has a strong 'weight' in the sphere of population and economy as it accounts for as much as one-fifth of their world volume. In terms of both population and population density, it occupies second place, and according to economic potential, it ranks third place among the macro-regions. Over the past 30 to 60 years, the integrating elements have been the high economic maturity, the high export potential and the dynamism of economic development. When it comes to maintaining this status, the most important factor is the production of electric energy. The states of this macro-region produce the most electric energy globally. In terms of transport, this macro-region also tops the global charts with the biggest ports and airports in the world. Problems relate primarily to the sphere of politics (over half a century of shaping relations between democratic and Communist states) and natural conditions (extreme pollution, especially in Chinese agglomerations, desertification, volcanism, earthquakes, tsunamis and shortage of water resources).

6. The Indonesian macro-region (South-Eastern Asia) is a separate macro-region, given the geographic isolation of Indonesia from the set of Islamic countries and given the high religious heterogeneity of the whole area, influenced both by the Chinese and Indian macro-regions. The role of a strong integrating instrument is played by the international organization ASEAN, founded to accelerate the economic growth of its member countries in 1967. This organization also strives to achieve progress in relation to social and cultural problems and to intensify bilateral relations. The strong integrating factor of this macro-region is a common colonial past and the fact that a large proportion of its area is island-based; it also has many straits and marginal seas, vital for transport both globally and inside the macro-region. Most of the countries of this area are denoted as 'Asian Tigers'. However, this macro-region, too, faces many problems of a physical geographic nature (volcanism, earthquakes and frequent landslides) and a sociogeographic nature (polarity between individual areas in the living standards of the population, as well as extreme linguistic diversity).

7. The Indian macro-region was delineated within the area of the former British India in order to preserve the integrity of the biggest population concentration in the contemporary world $(23.7 \%$ of global population). The following integrating factors exist: not only overpopulation, a high birth rate and both Hindu and Buddhist civilisations, but, unfortunately, economic underdevelopment, with the GDP per capita at the same level as in the African macro-region, which is by far the lowest among the macro-regions of the world (only 4,000 USD in 2015). There are also other specific features: an extremely high proportion of rural population, a low life expectancy (67 years for men and 70 years for women) and a literacy level of just $57 \%$. Thanks to the high birth rate, there has been a considerable growth in the population of this macro-region, although, due to a high emigration rate, the macro-region loses over two million people annually (mostly educated and economically successful young people). There are persisting ethnic, caste and religious tensions. When it comes to physical geography, there is a frequent problem of climatic anomalies (droughts, floods), numerous earthquakes and subsequent tsunamis; in addition, there is an exceptional dependence on the monsoon. This macro-region is one of the areas with a high (both spatial and social) internal differentiation.

8. The Islamic macro-region is delineated by a belt of primarily Muslim countries stretching from Morocco to Iran. Islamic religion and Islamic civilisation are the most important integrating factors, as well as the long, shared history. An integrating role is played by oil and gas mining, which is behind the robust economic growth; meanwhile, traditional forms of government persist alongside the concentration of power within a relatively narrow group of extremely rich families. Despite the fairly high homogeneity, there are still internal cultural and ethnic discrepancies, resulting in extreme tension. The macro-region is among the most conflict-ridden areas of the present-day world.

9. The Latin American macro-region spreads along the American continent up to the border of the USA with Mexico. It is a strongly integrated region with a specific culture, where a 
Table 2. Macro-regions of the world according to population and GDP (2016)

\begin{tabular}{|c|c|c|c|c|c|}
\hline \multirow{2}{*}{$\begin{array}{c}\text { Macro- } \\
\text { region }\end{array}$} & Population & & GDP & & $\begin{array}{c}\text { GDP } \\
\text { ppp }\end{array}$ \\
\cline { 2 - 6 } & million & $\%$ & billion & $\%$ & USD \\
\hline 1 European & 541 & 7.3 & 19.4 & 25.6 & 38,000 \\
\hline $\begin{array}{c}\text { 2 Anglo- } \\
\text { American }\end{array}$ & 363 & 4.9 & 19.2 & 25.3 & 54,000 \\
\hline 3 Russian & 286 & 3.8 & 2.4 & 3.2 & 18,000 \\
\hline $\begin{array}{c}\text { 4 Australian- } \\
\text { Oceanic }\end{array}$ & 39 & 0.5 & 1.7 & 2.2 & 35,000 \\
\hline $\begin{array}{c}\text { 5 Sino- } \\
\text { Japanese }\end{array}$ & 1,668 & 22.6 & 16.7 & 22.0 & 16,000 \\
\hline 6 Indonesian & 629 & 8.5 & 2.2 & 2.9 & 10,000 \\
\hline 7 Indian & 1,755 & 23.7 & 2.6 & 3.4 & 4,000 \\
\hline 8 Islamic & 502 & 6.8 & 4.3 & 5.8 & 17,000 \\
\hline $\begin{array}{c}\text { 9 Latin } \\
\text { American }\end{array}$ & 630 & 8.5 & 5.6 & 7.4 & 16,000 \\
\hline 10 African & 994 & 13.4 & 1.7 & 2.2 & 4,000 \\
\hline Total & 7,407 & 100.0 & 75.8 & 100.0 & 10,000 \\
\hline
\end{tabular}

Notes: GDP ... Gross Domestic Product, GDP ppp ... Gross Domestic Product based on purchasing power parity, USD ... United States dollar. Source: the World Bank, the CIA World Factbook, the United Nations

decisive role is played not only by shared Romance languages and religion, but also by a high rate of urbanization and very low population density. The region faces the problem of rampant crime and the associated large-scale drug dealing as well as the biggest global discrepancies between rich and poor. For decades, the region has suffered from strained relations between populist leaders or parties (including the Communist ones) and rightist regimes.

10. The African macro-region comprises the states situated to the south of Morocco, Libya and Egypt. It has the biggest area, spreading across $18.4 \%$ of the global landmass. The cementing elements of the region appear in the form of poverty, illiteracy (onethird of the population is illiterate), epidemics, overpopulation, ethnic tension, and the colonial past of the macro-region. There is a dominance of undemocratic regimes, often ruled by armed forces. The macro-region is typically characterized by a high level of corruption and 'tribalism' (advocacy of kinship and clan interests in politics, Kolská 2017). Also known as 'Sub-Saharan Africa', this macro-region only creates $2 \%$ of the nominal value of the created 'global GDP' (Figure 2). Although its GDP is growing by some $8-10 \%$ annually from a low base, the GDP per capita still remains at a very low level, being the lowest among the macro-regions.

According to social and economic development, the macroregions are structured into several groups. Clearly, the most advanced are the European and Anglo-American macro-regions, creating over one half of the global economic production. In terms of maturity and GDP per capita, they are joined by the AustralianOceanic macro-region. Socially and economically, the Russian and Sino-Japanese macro-regions are comparable; similar figures can also be found in the Islamic and Latin American macro-regions. The most critical situation is found in the Indian and African macro-regions, where the GDP per capita according to the purchasing power is ten times lower than in Europe. Over one-third of their population is illiterate. The Indonesian macro-region lies in between these two groups, with relatively good conditions for further development. This primarily relates to social aspects and the high literacy rate. A vital feature that emerges when comparing the macro-regions is the fact that the advanced macro-regions have a low internal economic and cultural differentiation (they are more homogeneous), while these internal differentiations are highest in the poorest macro-regions (see Table 1).

\section{Discussion and conclusions}

Naturally, this topic requires elaboration, which should focus on two elements: professional and educational levels. As the state of regional knowledge is very bad in Czechia at present, we wanted to prepare a publication concentrated on regional geography that would also serve as a textbook providing a basic overview of the macro-regions of the world for the study of geography at university level (Andèl et al. 2017). The professional elaboration aims to observe the development of the macro-regions delineated in this way from the viewpoint of the development trends of the current globalized world (the problem of growing/ diminishing differences between macro-regions, or the question of whether there is a dominance of divergent/convergent trends when the development of the global system is assessed). Another viewpoint is that of geopolitical forces; furthermore, efforts have been made to specify and try to explain the existence of problem areas/macro-regions and existing conflicts (Hampl 2014). Questions arise in relation to the 'tension' between advanced, rich macro-regions on the one hand and poor, backward macroregions on the other. According to Wallerstein (1979), the world is divided into an advanced core, an intermediate semi-periphery and a backward periphery. This raises the question of whether conflicts arise more often in peripheral macro-regions because the core and semi-periphery exploit them. Or, rather, do they arise there because they are outside the main area of interest, meaning that forces appear there which would be under control in more advanced countries? Another topic for consideration is the 'clashes of civilisations' in Huntington's concept within the framework of global macro-regions. Research also needs to be carried out on the macro-regions of the globalized world (people using e-mails, satellite phones, televisions and payment cards and freely roaming the whole world) and the marginalized world, full of 'forgotten' people, who have to make do with traditional forms of livelihood or humanitarian aid (Kaldorová 2001).

Our deliberations did not include the situation that arose as a result of the disintegration of the USSR and Russia's current effort to install its successor in the form of the Eurasian Union. This can be seen as a response to the unipolar world of the late 1990s on the part of Russia, which has never reconciled itself with the loss of its position in the former 'bipolar world'. China's economic and political rise in the past decade has confirmed the previous trends of economic development, with crucial volumes of global production and development concentrated on the Pacific coast, both in the USA and, above all, in Eastern and South-Eastern Asia (Tomeš et al. 2007). In addition, the dynamic changes occurring in some countries denoted until recently as 'developing' (China, India, South Africa, Brazil, Mexico and Russia) will undoubtedly cause pressures that might influence the future division of the world into macro-regions, as well as the position of these macro-regions in the world. The problems of immigration from developing countries should also be stressed. When it comes to this topic, Europe in particular is unable to create an active defence against the influx of migrants from the Middle East and Africa. At present, Africa has over one billion inhabitants, but forecasts from this century speak of at least a doubling of the African population. This will undoubtedly translate into pressure, especially on Europe. Will it still be the macroregion described here in twenty years' time? 
The deliberations presented here are not definitive because the global system is dynamic, constantly developing. They should be supplemented with some more dimensions to broaden their approach to global issues by looking for some perspective. The first is the stability of the current macro-regions and their internal heterogenization. However, given a topic as complex as the division of the world into macro-regions, this is a very complicated question. The second dimension is the question of so far unfound or even unknown raw materials which could influence the present state of the distribution of macro-regions, the position of individual states and their transformation in the increasingly interconnected world of the future. 'Spatial reserves' should be included here; however, these are only at the disposal of some states or macro-regions (Hampl 2010). In our view, the third dimension is the intensifying division of the population of individual countries, both from the perspective of their education (we have in mind not only reading and counting, but, above all, the ability to engage in continued learning, as well as language and computer skills) and in terms of their incomes, life objectives and prospects. Similar deliberations go beyond the framework of the topic discussed, but their impact on the search for the future development of global macro-regions cannot be denied.

\section{References}

Agnew, J 1999, 'Regions on the mind does not equal regions of the mind', Progress in Human Geography, vol. 23(1), pp. 91-96.

Anděl, J \& Bičík, I 2015, 'Geografické makroregiony světa', Geografické rozhledy, vol. 24(3), pp. 2-5.

Anděl, J, Bičík, I \& Bláha, JD 2018, 'Concepts And Delimitation Of The World's Macro-Regions', Miscellanea Geographica - Region al Studies on Development, vol. 22(1), pp. 16-21.

Anděl, J, Bičík, I \& Zavadská, K 2017, 'The World's Major Regions as Part of Regional Geography Courses?' in Current Topics in Czech and Central European Geography Education, eds. P Karvánková, D Popjaková, M Vančura \& J Mládek, Springer, pp. 211-227.

Bičík, I, Anděl, J, Havliček, T \& Matějček, T 2010, Makroregiony světa, Nakladatelství České geografické společnosti, Prague.

Bláha, JD \& Nováček, A 2016, 'How Central Europe is Perceived and Delimited', Mitteilungen der Österreichischen Geographischen Gesellschaft, vol. 158, pp. 193-214.

Clawson, X \& Airriess, ChA 2007, World Regional Geography: A Development Approach, Prentice Hall, Cloth.

Cole, J 1996, Geography of the World's Major Regions, Routledge, New York.

De Blij, HJ \& Muller, PO 1997, Geography: Regions and Concepts, Wiley, New York.

Hampl, M 2009, 'Globální systém: stav, současné tendence a možné perspektivy distribuce mocenského potenciálu', Geografie, vol. 114(1), pp. 1-20.

Hampl, M 2010, 'Regionální diferenciace společnosti: Obecné typy vývojových procesư', Geografie, vol. 115(1), pp. 1-20.

Hampl, M 2014, 'Je nástup konvergenčních tendencí v diferenciaci globálního systému potvrzením obecných představ o vývoji územních a sociálních hierarchií?', Geografie, vol. 119(1), pp. 26-49.
Hobbs, JJ \& Dolan, A 2009, World regional geography, Brooks/ Cole, Belmont, CA.

Huntington, S 1996, The Clash of Civilizations and the Remaking of World Order, Simon and Schuster, New York.

Jackson, RH \& Hudman, LE 1990, World Regional Geography, Wiley, New York.

Kaldor, M 2001, New and Old Wars: Organized Violence in a Global Era. Polity Press, Cambridge.

Kolská, Z jr. 2017, Prezentace makroregionů světa ve vysokoškolském prostředí-Asijské makroregiony. Bachelor Thesis. JE Purkyně University, Ústí nad Labem.

Morris, JW 1972, World Geography. McGraw-Hill, New York.

Polonský, F, Novotný, J \& Lysák, J 2010. 'Cognitive Mapping of Major World Regions among Czech Geography Students', Journal of Maps, vol. 6(1), pp. 311-318.

Saarinen, TF 1988, 'Centering of Mental Maps of the World', National Geographic Research, vol. 4(1), pp. 112-127.

United Nations 2012, Standard Country or Area Codes for Statistical Use, Statistical Services Branch Statistics Division United Nations, New York, Available from: <http://unstats. un.org/unsd/methods/m49/m49.htm>. [11 January 2018].

Taylor, PJ \& Flint, C 2000, Political geography: world-economy, nation-state and locality. Prentice Hall, Harlow.

Tomeš, J, Festa, D \& Novotný, J 2007, Konflikt světů a svět konfliktů: strety idejí a zájmů $v$ současném světě. P3K, Prague.

Wallerstein, I 1979, The Capitalist World - Economy. Cambridge University Press, Cambridge, MA. 